\section{C677T polymorphism of the MTHFR gene and variant hemoglobins: a study in newborns from Salvador, Bahia, Brazil}

\author{
Polimorfismo C677T no gene da MTHFR \\ e hemoglobinas variantes: um estudo \\ em recém-nascidos de Salvador, Bahia, Brasil
}

1 Centro de Pesquisas

Gonçalo Moniz,

Fundação Oswaldo Cruz, Salvador, Brasil.

2 Faculdade de Farmácia Universidade Federal da Bahia,Salvador, Brasil. 3 Faculdade de Medicina, Universidade Federal da Bahia,Salvador, Brasil.

Correspondence

Marilda Souza Gonçalves Laboratório de Patologia e Biologia Molecular, Centro de Pesquisas Gonçalo Moniz, Fundação Oswaldo Cruz. Rua Waldemar Falcão 121 Salvador, $B A$ 40295-001, Brasil. mari@cpqgm.fiocruz.br

\begin{abstract}
The C677T polymorphism in the methylenetetrahydrofolate reductase gene (MTHFR) is associated with an increase in total homocysteine serum levels (tHcy), described as a risk factor for cardiovascular disease. Eight hundred fortythree neonates from two different maternity hospitals, one public and another private, in Salvador, Bahia, Brazil were screened for this polymorphism by PCR and RFLP. The T-allele frequency in the total sample was 0.23 , and the prevalence rates of heterozygous and homozygous carriers were $36.2 \%$ and $5.3 \%$, respectively. The T-allele frequency differed and the T/T genotype was more prevalent at the private maternity hospital. The hemoglobin ( $\mathrm{Hb}$ ) profile was investigated by HPLC in 763 newborns. The frequency of variant $\mathrm{Hb}$ was higher at the public than at the private maternity hospital. The association of the C677T polymorphism and the $\mathrm{Hb}$ profile was investigated in 683 newborns, showing a relatively high frequency of variant Hbs and the T allele. These data could provide an important basis for further studies focusing on potential risks of vaso-occlusive events in these individuals.
\end{abstract}

Newborns Infant; Polymorphism; Hemoglobinopathies
Fábio David Couto 1

Elisângela Vitória Adorno 1,2 Joelma Figueiredo Menezes 1 José Pereira Moura Neto 1 Marco Antônio Vasconcelos Rêgo ${ }^{3}$ Mitermayer Galvão dos Reis 1 Marilda Souza Gonçalves 1,2

\section{Introduction}

Methylenetetrahydrofolate reductase (MTHFR) is a key enzyme in folate and homocysteine (Hcy) metabolism. A single point mutation causing a $\mathrm{C} \rightarrow \mathrm{T}$ substitution at nucleotide 677 of the MTHFR gene has been associated with a thermolabile enzyme form of low biological activity 1 . High total homocysteine (tHcy) serum or plasma levels have been attributed to the presence of the C677T MTHFR polymorphism, mainly in association with low folate and vitamin B12 levels 2,3,4. The role of high tHcy serum or plasma levels received considerable interest after these factors were implicated as an important risk factor for cardiovascular disease in a study examining children's aorta fragments 5; the study proposed that high homocysteine levels play a role in arteriosclerosis genesis.

Sickle-cell anemia (SS) is a monogenic disorder with worldwide distribution and high prevalence in Brazil 6. The mutant sickle hemoglobin results from a single nucleotide substitution: (GAG $\rightarrow$ GTG) at the sixth codon of the beta-globin gene. Sickle cell anemia displays a heterogeneous clinical presentation, unpredictable clinical development, and is characterized by chronic hemolytic anemia and vasoocclusive events that result in acute pain crises, with chronic and progressive tissue damage 7. Vascular alterations are commonly observed among these patients 8 , and SS and SC disease 
carriers have an increased risk of arterial vascular disease and venous thrombosis 9 .

The high turnover of red blood cells (RBC) observed in sickle-cell patients is associated with lower serum levels of folate and vitamin B12 10, leading to the increased tHcy serum or plasma levels that have been implicated in vascular endothelium injury 11. Even in the absence of genetic predisposition or traditional risk factors such as $\mathrm{C}$-reactive protein and MTHFR, the increased tHcy levels have been considered an important predictor of mortality in patients with angiographically defined coronary artery disease 12 .

Bahia, a State in Northeast Brazil, has a high interethnic admixture. The strong African gene pool 13 has resulted in a high frequency of hemoglobinopathies, with a prevalence of S heterozygotes (AS) reaching 14\% in groups of African descendants 14 . In this article we report on a molecular characterization of the C677T MTHFR gene polymorphism in a newborn population from two different maternity hospitals in Salvador, investigating its association with the presence of variant hemoglobins.

\section{Material and methods}

\section{Subjects}

A total of 843 newborns were studied. After obtaining approval from the Research Ethics Committee of the Oswaldo Cruz Foundation, we enrolled newborns from the Tsylla Balbino public maternity hospital and the Santo Amaro private maternity hospital. Although both are located in Salvador, the socioeconomic characteristics of women giving birth at these two hospitals are quite different. Sample collection occurred from May to December 2000. Eight hundred forty-three newborn babies were screened for the C677T MTHFR gene polymorphism and 763 for the hemoglobin profile.

\section{Blood collection}

Pediatricians and nurse staff collected a cordblood sample from each infant, using EDTA anticoagulant. Samples were refrigerated at $4 \mathrm{oC}$ for a maximum of eight hours before the hemoglobin profile investigation.

\section{Hemoglobin analysis}

Hemoglobin analyses were performed by cationexchange high performance liquid chromatography (HPLC) (BioRad Variant ${ }^{\circledR}$, California,
USA), according to the manufacturer's instructions.

\section{DNA extraction}

DNA was isolated from cord-blood leukocytes using the GFX ${ }^{\circledR}$ Genomic Blood DNA Purification KIT (Amersham Pharmacia Biotech Inc., Piscataway, USA), following the manufacturer's instructions.

\section{C677T MTHFR gene polymorphism}

C677T MTHFR gene polymorphism was investigated by PCR, as previously described by Frosst et al. 1. The generated 198 bp PCR product was digested by the Hinf I restriction enzyme (New England BioLabs Inc., Tozer Road, Beverly, MA, USA), resulting in 175 and $23 \mathrm{bp}$ fragments in the homozygous T state, and 198, 175 , and $23 \mathrm{bp}$ fragments in heterozygotes. The wild type remains undigested, preserving the original $198 \mathrm{bp}$ fragment.

\section{Results}

The total T-allele frequency was 0.23 , with a prevalence of 36.2 and $5.3 \%$ for the $\mathrm{C} / \mathrm{T}$ and $\mathrm{T} / \mathrm{T}$ genotypes, respectively. However, the allele frequency was higher among newborns of the Santo Amaro maternity hospital than from the newborns of the Tsylla Balbino maternity hospital, with a statistically significant difference from the T/T genotype distribution (Table 1).

As shown in Table 2, out of 763 newborns, 60 were FAS heterozygotes ( 53 from Tsylla Balbino and seven from Santo Amaro); 30 were FAC heterozygotes (27 from Tsylla Balbino and three from Santo Amaro); one was FC, six were FSC, and one was FS (all from Tsylla Balbino). The frequency of variant hemoglobins was higher at the Tsylla Balbino than the Santo Amaro maternity hospital, with a statistically significant difference for FAS, $\chi^{2}=14.14$ and $p$ value $<0.001$, and for FAC genotype distributions, $\chi^{2}=7.80$ and $p$ value $=0.005$. The observed relationship between the C677T MTHFR gene polymorphism and different hemoglobin patterns was established in a total of 683 samples (Table 3).

\section{Discussion}

The T-allele frequency of the C677T MTHFR polymorphism has been found to vary among different populations and ethnic groups, with a 
lower frequency among Africans 15. Krieger et al. 13 estimated in a sample from Northeast Brazil that it was some $97 \%$ of the way to interethnic panmixia. An intensive African slave trade occurred from the 16th the 19th centuries 16 , and more than five million Africans of several nationalities entered Brazil between 1850 and 1950 17. In Brazil, Arruda et al. 18 found a Tallele frequency of $10 \%$ among people of European descent; $1.45 \%$ among Blacks; and $1.2 \%$ among Indians. Perez et al. 19, studying children with spina bifida and controls, found prevalence rates for the $\mathrm{T} / \mathrm{T}$ genotype of 7.64 and $10.32 \%$, respectively. The T-allele frequency of 0.23 and the prevalence of $\mathrm{C} / \mathrm{T}$ and $\mathrm{T} / \mathrm{T}$ genotypes found in this report were higher than those observed in other studies of African and African-descent populations worldwide $20,21,22$ and lower than those found in studies of Europeans 23. This result was probably influenced by the high rate of racial admixture in the Bahian population. The T/T genotype displayed a statistically significant difference between the groups of newborns from the two maternity hospitals, with a lower frequency at the Tsylla Balbino maternity Hospital. The mothers who gave birth at the Santo Amaro maternity hospital are primarily representative of the European-descendent portion of the Bahian population, confirming the higher T-allele frequencies previously described in this continental group 24 .

In contrast to the C677T MTHFR gene polymorphism distribution, the variant hemoglobin frequencies were higher at the Tsylla Balbino than at the Santo Amaro maternity hospital. These differences are probably due to the ethnic composition of the newborns from the two hospitals. Azêvedo et al. 14 showed an increase in variant hemoglobin allele frequencies in European-descendent Bahians, which were not restricted to African-descendent groups, but with intermediate numbers among mulattos.

The frequencies of $\mathrm{C} / \mathrm{T}$ or $\mathrm{T} / \mathrm{T}$ genotypes among FAS newborns were $35.7 \%$ and $5.4 \%$, respectively. The T-allele presence has been associated with increased tHcy serum levels. Khajuria \& Houston 25 show in vitro evidence of a direct mechanism by which homocysteine, at physiologically and pathophysiologically relevant concentrations, may induce thrombosis.

Even though sickle cell patients routinely using folic acid to improve erythropoiesis, folate status can be found at sub-clinical levels when compared to $\mathrm{Hb} \mathrm{AA}$ normal control serum folate levels 10. Lowenthal et al. 26 hypothesized that the concentration of folate required to normalize plasma homocysteine lev-
Table 1

Prevalence of the C677T MTHFR gene polymorphism among 843 newborns from the Tsylla Balbino and Santo Amaro maternity hospitals. Salvador, Bahia, Brazil, 2000.

\begin{tabular}{lccc}
\hline Genotype & Tsylla Balbino (\%) & Santo Amaro (\%) & Total (\%) \\
\hline C/C & $379(61.0)$ & $114(51.4)$ & $493(58.5)$ \\
$\mathrm{C} / \mathrm{T}$ & $216(34.8)$ & $89(40.1)$ & $305(36.2)$ \\
$\star \mathrm{T} / \mathrm{T}$ & $26(4.2)$ & $19(8.6)$ & $45(5.3)$ \\
Total & $n=621$ & $n=222$ & $n=843$ \\
Allele & Allele frequency & Allele frequency & Allele frequency \\
$\mathrm{C}$ & 0.78 & 0.71 & 0.77 \\
$\mathrm{~T}$ & 0.22 & 0.29 & 0.23 \\
\hline
\end{tabular}

$n=$ number of samples; ${ }^{*}$ Differences in T/T genotype, $\chi^{2}=8.08 ; p=0.004$.

Table 2

Hemoglobin profile distribution among newborns from the Tsylla Balbino and Santo Amaro maternity hospitals. Salvador, Bahia, Brazil, 2000.

\begin{tabular}{lccc}
\hline $\begin{array}{l}\text { Hemoglobin } \\
\text { pattern }\end{array}$ & Tsylla Balbino (\%) & Santo Amaro (\%) & Total (\%) \\
\hline FA & $421(82.7)$ & $244(96)$ & $665(87.2)$ \\
FAS* & $53(10.4)$ & $7(2.8)$ & $60(7.9)$ \\
FAC** & $27(5.3)$ & $3(1.2)$ & $30(3.9)$ \\
FC & $1(0.2)$ & - & $1(0.1)$ \\
FSC & $6(1.2)$ & - & $6(0.8)$ \\
FS & $1(0.2)$ & - & $1(0.1)$ \\
Total & $\mathrm{n}=509$ & $\mathrm{n}=254$ & $\mathrm{n}=763$ \\
\hline
\end{tabular}

$n=$ number of samples; ${ }^{\star} \chi^{2}=14.14$ and $p$ value $<0.001$;

$\star \star \chi^{2}=7.80$ and $p$ value $=0.005$.

Table 3

The C677T MTHFR polymorphism and hemoglobin patterns among 683 newborns from the Tsylla Balbino and Santo Amaro maternity hospitals. Salvador, Bahia, Brazil, 2000.

\begin{tabular}{lcccc}
\hline $\begin{array}{l}\text { Hemoglobin } \\
\text { profile }\end{array}$ & \multicolumn{3}{c}{ C677T MTHFR gene Polymorphism } \\
& C/C (\%) & C/T (\%) & T/T (\%) & Total \\
\hline FA & $349(59)$ & $211(35.6)$ & $32(5.4)$ & 592 \\
FAS & $33(58.9)$ & $20(35.7)$ & $3(5.4)$ & 56 \\
FAC & $18(66.7)$ & $8(29.6)$ & $1(3.7)$ & 27 \\
FC & - & $1(100.0)$ & - & 1 \\
FSC & $4(66.6)$ & $1(16.7)$ & $1(16.7)$ & 6 \\
FS & - & $1(100.0)$ & - & 1 \\
Total & $n=404$ & $n=242$ & $n=37$ & $n=683$
\end{tabular}

$n=$ number of samples. 
els in patients with sickle cell disease may be higher than that of normal controls, and that patients with sickle cell disease have a higher nutritional requirement for folic acid than the general population. These facts can contribute to raising tHcy serum levels, described as a risk factor for coronary artery disease 27 . The T-allele presence found in the newborns in this study could provide an important basis for further studies focusing on potential risks of vasoocclusive events in these individuals.

The Bahia State Foundation for Hematology and Transfusion Therapy (HEMOBA) has regis- tered 942 SS patients, and data from the neonatal screening program for variant hemoglobins from APAE (the Association of Parents and Friends of Children with Disabilities) in Salvador, Bahia reports one SS for every 423 newborns. Blood samples from these SS patients and newborns can be referred to specialized laboratories to perform molecular investigation of the C677T polymorphism in the MTHFR gene. In our opinion, polymorphisms in genes responsible for folate and homocysteine metabolic pathways should be investigated in Bahia and other SS populations worldwide.

\section{Resumo}

O polimorfismo C677T no gene da MTHFR tem sido associado ao aumento dos niveis séricos de homocisteína.total ( $t H c y)$, descrito como fator de risco para o desenvolvimento de doenças cardiovasculares.Oitocentos e quarenta e três recém-nascidos (RNs), de duas maternidades diferentes, uma pública e a outra privada, em Salvador, Bahia, Brasil foram triados para o polimorfismo C677T por PCR e RFLP. A freqüência do alelo $T$ foi de 0,23 e as prevalências dos genótipos $C / T e$ $T / T$ foram de $36,2 \%$ e 5,3\%, respectivamente. A freqüencia do alelo $T$ diferiu e a prevalência do genótipo T/T foi mais elevada entre os RNs da maternidade privada. O perfil de hemoglobinas $(\mathrm{Hb})$ foi determinado por HPLC em 763 RNs. A freqüência de Hbs variantes foi mais elevada entre os RNs da maternidade pública Tsylla Balbino do que na maternidade privada do Hospital Santo Amaro. A associação do polimorfismo C677T e o perfil de Hbs foram estudados em 683 RNs, apresentando freqüência elevada da coexistência do alelo Te Hb variantes. Estes resultados podem ser utilizados como base para estudos futuros sobre riscos potenciais de eventos vaso-oclusivos nestes indivíduos.

Recém-nascidos; Polimorfismo; Hemoglobinopatias

\section{Contributors}

F. D. Couto participated in the blood sample collection in the hospitals, hemoglobin analysis, DNA extraction, molecular analyses, and drafting of the manuscript. E. V. Adorno, J. F. Menezes, and J. P. Moura Neto participated in the blood sample collection in the hospitals, hemoglobin analysis, and DNA extraction. M. Rego participated in the statistical analysis. M. G. Reis participated in the interpretation of the results and drafting and revision of the manuscript. M. S. Gonçalves supervised the laboratory analyses, interpretation of the results, and drafting and revision of the manuscript.

\section{Acknowledgements}

We wish to thank the directors, physicians, and nurses from the Tsylla Balbino and Santo Amaro maternity hospitals for their assistance in cord-blood collection. We are grateful to Craig Milroy for an English review and the Bahia State Central Laboratory for providing all the equipment necessary for biochemical analyses. 


\section{References}

1. Frosst P, Blom HJ, Milos R. A candidate genetic risk factor for vascular disease: a common mutation in methylenetetrahydrofolate reductase. Nat Genet 1995; 10:111-3.

2. D'Angelo A, Coppola A, Madonna P, Fermo I, Pagano A, Mazzola $G$, et al. The role of vitamin $B_{12}$ in fasting hyperhomocysteinemia and its interaction with the homozygous C677T mutation of the methylenetetrahydrofolate reductase (MTHFR) Gene. Thromb Haemost 2000; 83:563-70.

3. Pullin CH, Ashifielg-Watt PAL, Burr ML, Clark ZE, Lewis MJ, Moat SJ, et al. Optimization of dietary folate or low-dose folic acid supplements lower homocysteine but do not enhance endothelial function in healthy adults, irrespective of the methylenetetrahydrofolate reductase (C677T) genotype. J Am Coll Cardiol 2001; 38:1799-805.

4. Sunder-Plassmann G, Fodinger M. Genetic determinants of the homocysteine level. Kidney Int 2003; 84:141-4.

5. McCully KS. Vascular pathology of homocysteinemia: implications for pathogenesis of arteriosclerosis. Am J Pathol 1969; 56:111-28.

6. Zago MA, Costa FF. Hereditary haemoglobin disorders in Brazil. Trans R Soc Trop Med Hyg 1985; 79:385-8.

7. Serjeant GR. Sickle-cell disease. Lancet 1997; 350:725-30.

8. Ohene-Frempong K, Weiner SJ, Sleeper LA, Miller S, Embury S, Moohr JW, et al. Cooperative study of sickle cell disease. Cerebrovascular accidents in sickle cell disease: rates and risk factors. Blood 1998; 91:288-94.

9. Powars D, Wilson B, Imbus C, Pegelow C, Allen J. The natural history of stroke in sickle cell disease. Am J Med 1978;65:461-71.

10. van der Dijs FLP, Schong J, Brouwer DAJ, Velvis HJR, van den Berg GA, Bakker AJ, et al. Elevated homocysteine levels indicate suboptimal folate status in pediatric sickle cell patients. Am J Hematol 1998; 59:192-8.

11. Thambyrajah J, Townend JN. Homocysteine and atherothrombosis - mechanisms for injury. Eur Heart J 2000; 21:967-74.

12. Anderson JL, Muhlestein JB, Horne BD, Carlquist JF, Bair TL, Madsen TE, et al. Plasma homocysteine predicts mortality independently of traditional risk factors and C-reactive protein in patients with angiographically defined coronary artery disease. Circulation 2000; 102:1227-32.

13. Krieger H, Morton NE, Mi MP, Azêvedo E, FreireMaiaA, Yasuda N. Racial admixture in north-eastern Brazil. Ann Hum Genet 1965; 29:113-25.

14. Azevedo ES, Alves AF, Da Silva MC, Souza MG, Muniz DLAM, Azevedo WC. Distribution of abnormal hemoglobins and glucose-6-phosphate dehydrogenase variants in 1200 school children of Bahia, Brazil. Am J Phys Anthropol 1980; 53: 509-12.

15. Fletcher O, Kessling AM. MTHFR Association with arteriosclerotic vascular disease. Hum Genet 1998; 103:11-21.

16. Freyre G. Casa-grande e senzala. Rio de Janeiro: Editora Record; 2000.
17. Azêvedo E. Historical note on inheritance of sickle cell anemia. Am J Hum Genet 1973; 25:457-8.

18. Arruda VR, Siqueira LH, Gonçalves MS, von Zuben PM, Soares MC, Menezes R, et al. Prevalence of the mutation $\mathrm{C} 677 \rightarrow \mathrm{T}$ in the methylene tetrahydrofolate reductase gene among distinct ethnic groups in Brazil. Am J Med Genet 1998; 78:332-5.

19. Perez AB, D'Almeida V, Vergani N, De Oliveira AC, De Lima FT, Brunoni D. Methylenetetrahydrofolate reductase (MTHFR): incidence of mutations C677T and A1298C in Brazilian population and its correlation with plasma homocysteine levels in spina bifida. Am J Med Genet 2003, 119:20-5.

20. McAndrew PE, Brandt JT, Pearl DK, Prior TW. The incidence of the gene for thermolabile methylene tetrahydrofolate reductase in African Americans. Thromb Res 1996; 83:195-8.

21. Austin H, Hooper WC, Dilley A, Drews C, Renshaw M, Ellingsen D, et al. The prevalence of two genetic traits related to venous thrombosis in whites and African-Americans. Thromb Res 1997; 86:409-15.

22. Franco RF, Santos SE, Elion J, Tavella MH, Zago MA. Prevalence of the G20210A polymorphism in the 3'-untranslated region of the prothrombin gene in different human populations. Acta Haematol 1998; 100:9-12.

23. Motti C, Gnasso A, Bernardini S, Massoud R, Pastore A, Rampa P, et al. Common mutation in methylenetetrahydrofolate reductase. correlation with homocysteine and other risk factors for vascular disease. Atherosclerosis 1998;139:377-83.

24. Esfahani ST, Cogger EA, Caudill MA. Heterogeneity in the prevalence of methylenetetrahydrofolate reductase gene polymorphisms in women of different ethnic groups. J Am Diet Assoc 2003; 103:200-7.

25. Khajuria A, Houston DS. Induction of monocyte tissue factor by homocysteine: a possible mechanism for thrombosis. Blood 2000; 96:966-72.

26. Lowenthal EA, Mayo MS, Cornwell PE, ThornleyBrown D. Homocysteine elevation in sickle cell disease. J Am Coll Nutr 2000; 19:608-12.

27. Toft E, Ellegaard HV, Hagstrup CJ, Berg SE, Aarup $\mathrm{SH}$, Fog L, et al. Plasma homocysteine, angiographically proven coronary artery disease, and wine consumption. Eur J Intern Med 2003;14:2448.

Submitted on 28/May/2003

Final version resubmitted on $05 / \mathrm{Sep} / 2003$

Approved on 23/Oct/2003 